\title{
„Perło konchy tych krain, witam was, Bielany!” (o odkrywaniu urody Bielan i tajemnic kamedułów)
}

\section{1}

Zakon ojców kamedułów trwale wpisał się w dzieje Kościoła katolickiego w Polsce, a także naszej narodowej historii. Modlitwy, posty i milczenie pustelników - uczniów św. Romualda od czterech wieków stanowią wyjątkowo piękny przykład służby Bożej w Polsce. Ich obecność na naszych ziemiach, cicha i oddalona od zgiełku spraw codziennych, ukryta za murami eremów, długo nie wzbudzała wśród naszych przodków większego zainteresowania. Pierwsze szersze informacje o nich przekazał wkrótce po ich wprowadzeniu się na Srebrną Górę Szymon Starowolski, autor czterech łacińskich mów im poświęconych ${ }^{1}$. Autor ten zamieścił także krótki opis siedziby kamedułów bielańskich w wydanym w 1632 roku łacińskim dziele pt. Polonia ${ }^{2}$. Piotr Hiacynt Pruszcz, w Klejnotach stołecznego miasta Krakowa, które to dzieło jest uznawane za pierwszy „przewodnik” po kościołach krakowskich (wyd. w 1647 roku), poświęcił już Bielanom znacznie więcej miejsca. Wspomina on o pięciu męczennikach z XI wieku jako rzekomych członkach tego zakonu, pisze o przechowywanych na Bielanach rozlicznych relikwiach, a także o ostrej regule kamedułów, czego dowodzić ma m.in. fakt, że „Płci białogłow-

1 S. Starowolsci[i], Camaldula Argentini: sive de laudibus inclyti Camaldulensis ordinis, ff. eremitaru [m], prope Cracoviam, in monte Argentini, orationes IIII. Cracoviae 1623.

2 S. Starowolski, Polonia, Kolonia 1632. Pierwszy polski przekład, pióra W. F. Gołębiewskiego, ukazał się Wilnie w 1765 roku pt. Opisanie Królestwa Polskiego za Zygmunta III. We współczesnym przekładzie A. Piskały fragment ten brzmi: „Na zachód od miasta [Krakowa], o jedną milę, widzieć można na górze bardzo wyniosłej, zwanej Srebrną, klasztor ojców kamedułów przez wspomnianego już znakomitego męża, Mikołaja Wolskiego, wielkim sumptem zbudowany, gdzie wędrowiec zdumiewa się z tej przyczyny, że wszystko tu jest czynione dokładnie według proporcji geometrycznych w sztuce budowlanej obserwowanych (S. S., Polska albo opisanie położenia Królestwa Polskiego". Z języka łacińskiego przełożył, wstępem i komentarzami opatrzył A. Piskało, Kraków 1976, s. 83. 
skiej do kościoła nie puszczają, tylko trzy razy w rok"3. Znacznie obszerniejszą informację o bielańskich kamedułach zawarł Jędrzej Kitowicz w Opisie obyczajów za panowania Augusta III. Zajął się on kamedułami w części dzieła poświęconej działającym w Polsce za czasów ostatniego króla z dynastii Sasów rozlicznym zakonom. Główną uwagę skupił Kitowicz na opisie życia codziennego pustelników reguły św. Romualda. Zwrócił więc uwagę na to, jak się ubierają, co jedzą i piją (nigdy mięsa, nigdy alkoholu), jak odprawiają nabożeństwa, w jaki sposób grzebią zmarłych. Znamienne, że autor ten nie wspomina ani o trumnach, w których mieliby kameduli sypiać, ani o obowiązkowym ich milczeniu (o pozdrowieniu słowami memento mori wspomina tylko w swojej opowieści o kartuzach)4.

Całość Opisu obyczajów Kitowicza ogłosił Edward Raczyński późno, bowiem dopiero w latach 1840-1841. Przez kilkadziesiąt następnych lat trudno znaleźć jakąś wzmiankę o pustelnikach z Bielan. Ciszę wokół nich przerwał dopiero w 1871 roku krakowski historyk amator, wielce zasłużony dla poznania dziejów dawnego Krakowa, Ludwik Zarewicz. Stworzył on - w oparciu o bogate archiwa kamedułów z podkrakowskich Bielan - pierwszy zarys nie tylko bielańskiego eremu, ale w ogóle dziejów kamedułów na ziemiach polskich. Dzięki zawartej w jego pracy bogatej faktografii dzisiaj rozprawa jego traktowana jest także jako źródło historyczne ${ }^{5}$.

Zarewicz poświęcił sporo uwagi dramatycznym losom kamedułów w epoce narodowej niewoli. Pisał m.in.: „Mocarstwa zaborcze, poddając natychmiast eremy pod władzę diecezjalnych biskupów, wszelką styczność i znoszenie się zakonu z głównym eremem włoskim [tzn. z Góry Koronnej] surowo zabroniły. Nie tylko żaden wysłannik stamtąd nie miał wstępu do dawnych ziem polskich, ale nawet żadne uchwały kapituł generalnych nie mogły zakonników dochodzić. Tym sposobem zakon podobien do gałązki od pnia uciętej, zamierał z wycieńczenia, z braku soków żywotnych. Niebawem nastąpiły zabory majątków a nawet supresje pojedynczych eremów"'. Z pogromu, jaki urządzili kamedułom zaborcy, ocalały do dziś dwa eremy ${ }^{7}$.

3 P. H. Pruszcz, Klejnoty Stołecznego Miasta Krakowa albo Kościoly i co w nich jest widzenia godnego i znacznego przez P... H... P... krótko opisane, wydanie K. J. Turowskiego, Kraków 1861, s. 181.

4 Por. J. Kitowicz, Opis obyczajów za panowania Augusta III, oprac. R. Pollak, BN I 88, Wrocław 1951, s. 143-146.

${ }^{5}$ L. Zarewicz, Zakon kamedułów. Jego fundacje i dziejowe wspomnienia w Polsce i Litwie. Przeważnie według źródeł rękopiśmiennych archiwu[m] OO. Kamedułów w Bielanach przy Krakowie, Kraków 1871.

6 Tamże, s. 83-84.

7 Przykład Mikołaja Wolskiego sprawił, że w Rzeczpospolitej zaczęto fundować coraz nowe eremy kamedułów. W 1621 r. Jan Magnus Tęczyński, ostatni przedstawiciel rodu Tęczyńskich, 
Drogą wytyczoną przez Zarewicza w XX wieku poszła gromada innych badaczy. W pierwszej kolejności Stanisław Tomkowicz, autor wydanego w serii „Biblioteki Krakowskiej" popularnonaukowego zarysu monograficznego dziejów eremu bielańskiego pod Krakowem. Tomkowicz skupił się przede wszystkim na zagadnieniach związanych z wartością artystyczną bielańskiego kościoła, mniej na sprawie historii kamedułów, ale przecież znajdujemy w jego pracy urzekające opisy podkrakowskiej pustelni ${ }^{8}$. Jego kontynuatorami w prostej linii stali się liczni history-

ufundował erem w Rytwianach k. Połańca (w Ziemi Sandomierskiej). Pustelnia Złotego Lasu (Eremus Sylv Aurae) przetrwała do 1819 roku, kiedy decyzją arcybiskupa warszawskiego Franciszka Skarbka Malczewskiego klasztor zniesiono, a kościół pod wezwaniem Zwiastowania NMP przekazano pod zarząd proboszcza parafii w Połańcu. W 1641 roku król Władysław IV ufundował erem kamedulski na Bielanach pod Warszawą (Eremus Montis Regii). Erem ten został w 1912 roku przejęty przez ojców marianów. Dziś zespół klasztorno-kościelny na Bielanach warszawskich należy do Uniwersytetu Kardynała Stefana Wyszyńskiego. W 1663 roku staraniem Alberta Kadzidłowskiego, kasztelana inowrocławskiego, powstał erem kamedulski w Bieniszewie k. Kazimierza Biskupiego, na Ziemi Konińskiej (Eremus Quinque Martyrum), w miejscu, gdzie według tradycji u progu XI wieku miało zginąć śmiercią męczeńską pięciu przybyłych do Polski pierwszych uczniów św. Romualda. Klasztor ten został skasowany w 1819 roku. Staraniem Stanisława Mańkowskiego kameduli powrócili do Bieniszewa w 1937 r. Rozproszeni w czasie II wojny, powrócili tutaj po zakończeniu działań wojennych. Dziś jest to drugi - obok Bielan krakowskich - czynny na ziemiach polskich erem kamedulski. W 1667 roku król Jan Kazimierz ufundował erem kamedulski w Wigrach k. Suwałk (Eremus Insulae Wirgensis). Został on skasowany przez władze pruskie w 1797 r. Na jego miejscu utworzyły władze pruskie - za zgodą Stolicy Apostolskiej - biskupstwo wigierskie, które jednak trwało tylko do 1817 roku (przeniesione zostało wówczas do Sejn). W XIX w. erem wigierski służył za stację dla pędzonych w głąb Rosji rekrutów polskich. Obecnie znajduje się w nim Dom Pracy Twórczej Ministerstwa Kultury i Sztuki. W tym samym 1667 roku Krzysztof Zygmunt Pac ufundował erem kamedulski w Pożajściu k. Kowna (na Litwie). Klasztor ten został skasowany w 1832 roku na mocy rozkazu carskiego, w ramach represji po powstaniu listopadowym (klasztor objęli wówczas bazylianie, którzy przebywali tam do 1915 roku; po nich klasztor przejęły ss. kazimierki). W 1722 roku margrabia Józef Władysław Myszkowski ufundował erem w Szańcu k. Pińczowa (Eremus Marchionalis). Erem został skasowany w 1819 roku.

8 Autor podaje kilka podstawowych informacji o życiu kamedułów, a także wciąż żywej na przełomie wieków XIX i XX tradycji wypraw krakowian i turystów na Srebrną Górę. We wstępnej partii książeczki czytamy więc, że Bielany stanowią cel „majówek młodzieży, spacerów turystów przyjeżdżających do naszego miasta, licznych w lecie wycieczek krakowian, szukających świeżego powietrza. Ciche zresztą ustronie raz w roku, na Zielone Święta, zapełnia się różnobarwnym hałaśliwym tłumem. Z Krakowa i okolic podążają fiakry i furki chłopskie zielenią przybrane a natłoczone ludźmi; rodziny i całe towarzystwa rozkładają się tu na trawie wśród drzew cienistych; w rozbitych na polance namiotach i budach sprzedają się przekąski i napoje, między drzewami kołysza się huśtawki, zewsząd dolatują wesołe śpiewy i okrzyki pełne fantazji, nie brak i niewybrednych par tańczących na trawniku przy dźwiękach katarynki lub improwizowanej przedmiejskiej orkiestry, czyli tak zwanych zwierzynieckich mlaskotów. Słowem, przez dwa dni, 
cy sztuki, m.in.: Adam Małkiewicz, Jacek Gajewski czy Wojciech Kret. Ich prace, dotyczące głównie spraw architektury i wartości artystycznych bielańskiego eremu, weszły na trwałe do skarbca naszej wiedzy o kamedułach ${ }^{9}$. Trudną do przecenienia rolę w upowszechnieniu wiedzy o historii i życiu kamedułów polskich, w szczególności zaś kamedułów z Bielan krakowskich, posiadają wydane w ostatnich latach prace popularnonaukowe autorstwa Marzeny i Marka Florkowskich ${ }^{10}$. Do grona autorów upowszechniających wiedzę o Bielanach i kamedułach dołączył ostatnio także znakomity artysta fotografik: Adam Bujak, twórca wspaniałych albumów ${ }^{11}$.

\section{2}

Zanim przystąpimy do próby skreślenia dziejów „odkrywania” urody podkrakowskich Bielan oraz tajemnic mieszkających tam synów duchowych św. Ro-

jeżeli dopisze niepewna majowa pogoda, bywa tu rojno, gwarno i hucznie, pod bokiem zakonnej pustelni, mieszczącej okazały z trzema wieżami kościół, a u stóp jego w domkach z ogródkami rozsianych w środku lasu, kilkunastu białych mnichów św. Romualda, oddanych umartwieniu i kontemplacji. Po drugiej stronie tajemniczej bramy eremu jak rok długi panuje milczenie, przerywane tylko dzwonkiem zwołującym w dzień i w nocy mnichów na modlitwy i uderzeniami godziny na zegarze kościelnym, brzmiącymi w tej uroczystej ciszy jakby smętne przypomnienie, że każda godzina może być twoją ostatnią”, S. Tomkowicz, Bielany, Kraków 1906 („Biblioteka Krakowska” nr 26), s. 3-4.

9 Bogatą bibliografię prac poświęconych kamedułom, w tym kamedułom polskim, podaje Rafał Wiśniewski w rozprawie: Uwag kilka o eremach kamedulskich $w$ Rzeczypospolitej szlacheckiej, [w:] Historia bliższa i dalsza. Polityka - Społeczeństwo - Wojskowość. Studia z historii powszechnej i Polski, red. S. Kowal, G. Kucharski, M. Walczak, Poznań - Kalisz 2001, s. 161-225. Tu godzi się odnotować rozprawy przynajmniej kilku autorów. Są wśród nich: A. Małkiewicz, Zespół architektoniczny na Bielanach pod Krakowem (1605-1630), „Zeszyty Naukowe Uniwersytetu Jagiellońskiego. Prace z Historii Sztuki”, 1962, z. 1, nr 45; W. Kret, Problematyka artystyczna kościoła OO. Kamedułów na Bielanach pod Krakowem, „Kwartalnik Architektury i Urbanistyki”, 1967, t. 12; A. Małkiewicz, Z historycznej i artystycznej problematyki kościoła kamedułów na Bielanach pod Krakowem, „Zeszyty Naukowe Uniwersytetu Jagiellońskiego. Prace z Historii Sztuki”, 1972, z. 10, nr 102; J. Gajewski, Kościót i klasztor kamedułów na Bielanach pod Krakowem w świetle materiałów archiwalnych, „Biuletyn Historii Sztuki”, 1976, t. 38.

10 M. i M. Florkowscy, Kameduli, Kraków 2005; M. i M. Florkowscy, Przewodnik po eremie kamedułów na Bielanach w Krakowie, Kraków 2008. Por. także: F. Kupczyk, Kameduli w służbie Bogu i ludziom, Konin 2003.

11 A. Bujak, Tajemnice kamedułów, Kraków 2000; Bruno z Kwerfurtu, H. Samsonowicz (teksty), A. Bujak (fotografie), Legenda białych braci, Kraków 2009. 
mualda, godzi się w największym skrócie przywołać podstawowe informacje o przeszło czterowiekowej obecności kamedułów na polskiej ziemi. Obecność swoją tutaj zawdzięczają oni niezbyt szeroko znanemu możnowładcy polskiemu z XVI wieku, Mikołajowi z Podhajec Wolskiemu, herbu Półkozic (1553-1630), marszałkowi koronnemu z czasów Zygmunta III. Należał on do kręgu bliskich współpracowników króla Zygmunta III. Sprawował wysokie urzędy, król wysyłał go często w ważnych misjach dyplomatycznych za granicę.

Jak przypomniał w 1863 roku znakomity badacz naszej narodowej przeszłości, Julian Bartoszewicz ${ }^{12}$, a za nim Ludwik Zarewicz ${ }^{13}$, Mikołaj Wolski należał na przełomie XVI-XVII w. do elity ówczesnej Rzeczypospolitej. Od dzieciństwa związany był z obcymi dworami królewskimi. W wieku dziewięciu lat wysłany został przez rodziców do Grazu, na dwór arcyksięcia Maksymiliana, późniejszego pretendenta do tronu polskiego. Tu wychowywał się $\mathrm{w}$ towarzystwie dzieci arcyksięcia: Rudolfa, Macieja i Maksymiliana (kolejnego pretendenta do polskiego tronu). W 1574 roku Wolski został miecznikiem koronnym. Wkrótce jednak opuścił Polskę i zaczął kolejny etap swoich wypraw po Europie. Na kilkanaście lat osiadł znowu w Wiedniu (został podczaszym na dworze cesarza Rudolfa II, przyjaciela z młodzieńczych lat). Do Polski wrócił po wstąpieniu na tron Zygmunta III, który po pewnym czasie nadał mu godność marszałka wielkiego koronnego. Jak pisał Bartoszewicz, „Pan marszałek lubił ciągle podróżować. Ojczyzna niewiele dla niego miała uroku. Nazywali go Polacy «perpetuum viator», bo ciągle jeździł, miejsca nigdzie nie zagrzewając. [...] To zamiłowanie jego miało nawet swoje dobre strony. Wykształcił Wolski w sobie wysoko poczucie smaku, pokochał sztukę. Sprowadzał więc do Polski i osadzał w niej rzemieślników biegłych w różnych kunsztach. Budował także wiele, naśladując zagraniczne wzory. Wystawił pałace wspaniałe w Olkuszu, Kłobucku, Rabsztynie i Amanicach. [...] przyozdobił świetnie swoje starostwa, ale najwięcej Krzepice" ${ }^{14}$. Znakomicie wykształcony w zakresie prawa, Wolski pasjonował się także popularną w owych czasach alchemią ${ }^{15}$. Znał biegle oprócz łaciny języki: włoski, francuski i niemiecki.

12 J. Bartoszewicz, Mikołaj Wolski, marszałek wielki koronny, „Tygodnik Ilustrowany”, 1863, nr z 20 czerwca.

13 L. Zarewicz, Zakon kamedułów..., dz. cyt., s. 137-232.

14 J. Bartoszewicz, Mikołaj Wolski..., dz. cyt., s. 242.

15 Ludwik Zarewicz twierdzi, że współpracował dość długo ze znanym w całej Europie alchemikiem krakowskim Michałem Sędziwojem. Ich współpraca skończyła się jednak w sądzie: Sędziwój miał otrzymać od Wolskiego 3 tys. zł węgierskich, za które miał po kilku miesiącach 
Spośród licznych podróży zagranicznych Wolskiego szczególne znaczenie posiada jego wyprawa z 1602 roku w poselstwie od króla Zygmunta III do Rzymu, do papieża Klemensa VIII. Wolski został w czasie pobytu w Rzymie przyjęty przez papieża. W czasie audiencji miał wyznać Namiestnikowi Chrystusa, że przez 12 lat niesłusznie pobierał intraty z należnej Zakonowi Szpitalników Maltańskich komandorii poznańskiej. Klemens VIII miał mu wówczas nakazać sposób na naprawienie wyrządzonej Kościołowi krzywdy przez sprowadzenie do Polski jednego z zakonów ostrej reguły. Wolski zdecydował się na wybór ojców kamedułów - pustelników. Udał się też do eremu Monte Corona $\mathrm{k}$. Perugii, aby przedstawić władzom zakonu swoją propozycję otwarcia klasztoru kamedulskiego w Polsce. Mimo dość chłodnego przyjęcia (kameduli mieli obawiać się m.in. ostrego klimatu w Polsce, a także znacznego oddalenia od ich macierzystego domu) nie zraził się i kontynuował zabiegi o sprowadzenie ich do kraju nad Wisłą. Po powrocie do Krakowa zaczął szukać miejsca na osiedlenie się zakonników. Chodziło o miejsce oddalone od siedzib ludzkich, ale zarazem pięknie położone. Jego wybór padł na wznoszącą się nieopodal Krakowa górę bielańską. Wybór ten potwierdziła wkrótce 3-osobowa delegacja kamedułów włoskich, z o. Hieronimem z Perugii, przeorem klasztoru Monte Cucco Pascelupo na czele, którą w 1603 roku marszałek Wolski swoim kosztem sprowadził do Krakowa. Kłopot polegał jednak na tym, że góra ta nie była własnością marszałka Wolskiego, a należała do Sebastiana Lubomirskiego, jednego z najpotężniejszych naówczas magnatów polskich. Sprawę udało się ostatecznie przeprowadzić dzięki pomocy małżonki twórcy potęgi rodu Lubomirskich, Anny z Branickich Lubomirskiej. Za jej poradą marszałek Wolski użył podstępu w celu zdobycia dla kamedułów upatrzonej góry: wyprawił wielką ucztę, na którą zaprosił oprócz Lubomirskiego kwiat ówczesnej elity Krakowa, z biskupem krakowskim, świeżo mianowanym kardynałem Bernardem Maciejowskim na czele. Ujęty wymową Wolskiego, a także innych uczestników uczty (był wśród nich przychylny kamedułom Jerzy książę Zbaraski, późniejszy kasztelan krakowski) Lubomirski zgodził się przekazać górę kamedułom. Marszałek Wolski odwdzięczył się mu natychmiast, przekazując na pamiątkę tak owocnego spotkania srebrną zastawę stołową, przy której ucztowano. Dzięki temu wzgórze, które dotychczas nosiło nazwę Pagórków św. Stanisława, otrzymało nową nazwę: Srebrnej Góry.

oddać 30 tys. Oczywiście, Wolski pieniędzy tych nie otrzymał. Dopiero sąd (pod groźbą osadzenia na dożywocie w więzieniu) zmusił nieszczęsnego alchemika do zwrotu marszałkowi Wolskiemu pożyczonych pieniędzy. 
Dalsze losy bielańskich kamedułów potoczyły się już utartym w takich wypadkach torem. Mikołaj Wolski oraz Sebastian Lubomirski odpowiednio uposażyli zakonników, oddając im w 1604 roku we władanie wsie Mników, Mnikówek, Bielany a także wzmiankowaną Srebrną Górę. W roku następnym, 1605, położono kamień węgielny pod budowę złożonego z 20 domków eremu. W tym samym czasie przyjaciel marszałka Wolskiego, mieszczanin krakowski Paweł Henik, przywiózł z Włoch pięciu zakonników, którzy - w oczekiwaniu na erem bielański - pod wodzą wzmiankowanego o. Hieronima z Perugii osiedli tymczasowo w Bodzowie k. Tyńca (wieś była wówczas własnością tynieckich benedyktynów). W 1609 roku rozpoczęto na Srebrnej Górze budowę kościoła bielańskiego (miejsce pod kościół poświęcił nuncjusz Francesco Simoneta w dniu 4 maja tegoż roku). W roku następnym, 1610, kameduli przenieśli się z Bodzowa do domków pustelniczych na Bielanach. W dniu 28 lutego 1617 roku papież Paweł V nadał kościołowi i klasztorowi bielańskiemu odpusty ${ }^{16}$. Poświęcenie kościoła nastąpiło jednak późno, bo dopiero w dniu 14 września 1642 roku, w 12 lat po śmierci jego fundatora, marszałka Wolskiego, który zmarł w Przemyślu w dniu 9 marca 1630 roku i który - zgodnie z wolą wyrażoną w testamencie - został pochowany w szatach kamedulskich pod posadzką bielańskiego kościoła, przy wejściu, aby odwiedzający świątynię pątnicy mogli deptać jego "grzeszne ciało" ${ }^{17}$.

Historia ponad 400 lat obecności kamedułów na Bielanach obfituje w wydarzenia piękne, a także pełne grozy i tragedii. Klasztor bielański łupili Szwedzi i Rosjanie, Austriacy i Niemcy. Kroniki klasztoru zawierają sporo informacji o sprowadzanych na kamedułów „dopustach” Bożych, jak pożary (największy w 1814 roku), kontrybucje wojenne, zabór mienia. Niestety, znajdują się w nich

${ }^{16}$ W dokumencie tym wskazano liczbę dni, w których kościół kamedulski mogą odwiedzić kobiety. Ta tradycja trwa nadal, choć w czasie kolejnych wieków zmieniała się liczba dni „z dyspensą". Historycy wspominają, że były to dwa, trzy, wreszcie - sześć dni w roku. Obecnie kobiety mogą nawiedzać erem bielański dwanaście razy w roku: w Niedzielę Wielkanocną, Poniedziałek Wielkanocny, 3 maja (święto Matki Boskiej Królowej Polski), w święta Zesłania Ducha Świętego (Zielone Świątki), w pierwszą niedzielę po 19 czerwca (rocznica urodzin św. Romualda; dzień upamiętniający św. Protazego i św. Gerwazego), w drugą niedzielę lipca, w czwartą niedzielę lipca, w pierwszą niedzielę sierpnia, w dniu 15 sierpnia (Wniebowzięcie NMP), 8 września (święto Narodzenia NMP) oraz 25 grudnia (Boże Narodzenie).

${ }_{17} \mathrm{~W}$ testamencie swoim Wolski, który nie zostawił dziedzica, zapisał dodatkowo kamedułom dwie wsie: Malec i Ryczówek, a także - na utrzymanie kościoła - czynsz wieczysty w wysokości 1500 złr. Nadto zapisał im jeszcze kamienicę przy ul. Gołębiej 6 w Krakowie - na hospicjum dla zakonników przebywających w Krakowie. Kamienica ta - jako bodaj jedyna nieruchomość poza Bielanami - pozostaje do dziś własnością zakonników ze Srebrnej Góry. 
także epizody wstydliwe, a nawet gorszące ${ }^{18}$, które jednak nie mogą przesłonić całości obrazu. Nie brak bowiem w kronikach bielańskiego eremu informacji o chwilach wzniosłych, jak choćby wizyty wyjątkowych gości, w tym polskich królów. Wiadomo więc, że często bywał tu król Władysław IV, którego staraniem ozdobiona została kaplica pod wezwaniem św. Benedykta (zw. Królewską). Kronikarze dziejów eremu wspominają, że we wrześniu 1655 roku spędził na Bielanach jedną noc uchodzący z kraju na Śląsk król Jan Kazimierz. Z tarasu foresterii, czyli domu gościnnego (zwanego od XIX wieku Schindlerówką, dzisiaj zaś Domem Królewskim ${ }^{19}$ ), oglądał on pożar przedmieść Krakowa, niszczonych na rozkaz Stefana Czarnieckiego, dowodzącego obroną dawnej stolicy Polski ${ }^{20}$. W dwadzieścia lat później, u progu 1676 roku, biskup krakowski Andrzej Trzebicki przywiózł tutaj i na pewien czas złożył trumnę ze zwłokami tego nieszczęśliwego króla. Po wykonaniu nowej, okazałej trumny, doczesne szczątki Jana Kazimierza uroczyście przewieziono do podziemi katedry wawelskiej. W marcu 1671 roku zwiedził klasztor na Bielanach król Michał Korybut Wiśniowiecki ${ }^{21}$. Zaś w dniu 15 sierpnia 1683 roku przybył na Bielany król Jan III Sobieski wyprawiający się pod Wiedeń. Jedną noc z 27 na 28 października 1698 roku spędziła w domu gościnnym kamedułów bielańskich opuszczająca definitywnie Polskę królowa Maria Kazimiera, wdowa po Janie III Sobieskim. August II Sas spędził tu na rekolekcjach wielkopostnych cztery dni w Wielkim

18 O takich epizodach wspomina Ambroży Grabowski w swoich Wspomnieniach. Pisze on tam m.in., że w połowie XIX w. „kameduli bielańscy prowadzili gorszące życie; złożeni bowiem z ludzi prawie bez żadnego wykształcenia, zapomnieli o tym, że są anachoretami. Były pomiędzy nimi wewnętrzne zatargi, swary a nawet bójki; rozumie się, że gorzałka w tych znaczną odgrywała rolę" (A. Grabowski, Wspomnienia, wydał S. Estreicher, Kraków 1909, t. 2, s. 283).

19 Ks. Jan Schindler, prezes Senatu Rządzącego Wolnego Miasta Krakowa (1839-1846), kurator Uniwersytetu Jagiellońskiego w latach 1847-1849, profesor na Wydziale Teologicznym Uniwersytetu Krakowskiego (1832-1836), zasłużył się jako „ratownik” zabytków krakowskich. Odnowił m.in. Teatr Miejski przy pl. Szczepańskim, przeprowadził w latach 1840-1848 restaurację i przebudowę Collegium Maius, odrestaurował Barbakan, Bramę Floriańska i Wieżę Mariacką. Za jego kadencji jako prezesa Senatu Wolnego Miasta Krakowa wybrukowano wiele ulic krakowskich, rozpoczęto także budowę mostu na Wiśle (most Podgórski 1844-1850). W 1848 roku odrestaurował on kaplicę św. Jana Chrzciciela w kościele kamedułów, zaś w 1857 roku odnowił budynek foresterii i założył przy nim ogród. Odtąd budynek ten zaczęto zwać Schindlerówką.

20 Scenę tę uwiecznił przed laty Jan Matejko na obrazie zatytułowanym Jan Kazimierz patrzacy na płonący Kraków w czasie oblężenia przez Szwedów w roku 1655.

${ }^{21}$ Ludwik Zarewicz twierdzi, że król ten, jeszcze jako człowiek prywatny, w dniu 19 czerwca 1669 roku, służąc do mszy św. jednemu z kamedułów na Bielanach warszawskich, otrzymał wiadomość o wyborze na króla Polski, L. Zarewicz, Zakon kamedułów..., dz. cyt., s. 63. 
Tygodniu 1706 roku. Ostatni król polski, Stanisław August Poniatowski, odwiedził Bielany w dniu 23 czerwca 1787 roku, ale - jak pisze Zarewicz - przybył on na Srebrną Górę nie jako pątnik szukający wsparcia duchowego, lecz jako szukający wrażeń turysta.

W dziejach klasztoru kamedułów na Bielanach zapisali się także przedstawiciele świata polskiej kultury i sztuki. Wzmiankowany już tutaj Paweł Henik, członek Zakonu Maltańskiego, który z czasem przyjął biały habit kameduły, w 1623 roku przekazał na Bielany liczący ok. 1 tys. egzemplarzy księgozbiór, rozpoczynając $\mathrm{w}$ ten sposób dzieje tamtejszej biblioteki ${ }^{22}$. W tym samym roku jeden z największych ówczesnych pisarzy polskich, Szymon Starowolski, ogłosił zbiór łacińskich mów pochwalnych na cześć bielańskich kamedułów. Od 1617 roku aż do śmierci w 1660 roku, przez 43 lata, przebywał w tym eremie znakomity muzyk i kompozytor polski, o. Firman Gierlicki. W 1653 roku na Srebrnej Górze szukał schronienia przed zarazą biskup krakowski Piotr Gembicki. W 1758 roku odprawiał tu rekolekcje ks. Józef Załuski, mianowany biskupem krakowskim (człowiek wielce zasłużony dla polskiej kultury jako współtwórca tzw. Biblioteki Załuskich!). Wielekroć odwiedzał Bielany biskup-poeta Jan Paweł Woronicz. Bywał tu także inny biskup krakowski próbujący pióra, Ludwik Łętowski. Wielkie zasługi oddał kamedułom ks. Jan Schindler. Na Bielanach szukał wytchnienia kardynał Jan Puzyna. Spędził tu także kilka miesięcy 1885 roku Adam Chmielowski (św. Brat Albert). Odbywał rekolekcje na Bielanach ks. Franciszek Blachnicki. Wiele razy odwiedzał Srebrną Górę Karol Wojtyła, który bywał tu jako zwykły ksiądz, jako biskup krakowski, a także jako papież (w 2002 roku).

Wszystkie te fakty potwierdzają jedno: iż podkrakowskie Bielany zajmowały szczególne miejsce w życiu Polski. Przez całe wieki kamedułów otaczała jednak tajemnica. Przyczyniało się to także do powstawania fałszywych wyobrażeń o ich życiu. Sytuacja zmieniła się dopiero na początku XIX wieku. W pierwszej kolejności - dzięki krakowskim poetom.

22 Bibliotekę tę znacząco wzbogacił w 1678 roku kanonik krakowski ks. Jan Chryzostom Bodzęta, przekazując ojcom kamedułom swój księgozbiór (za co uzyskał zgodę na pochówek w podziemiach świątyni). Ludwik Zarewicz twierdzi, że swój księgozbiór przekazał kamedułom także ks. Jan Schindler, prezes Senatu Wolnego Miasta Krakowa. Obecnie licząca znacznie ponad 6 tys. egzemplarzy biblioteka ojców kamedułów, zaniedbana i narażona na rozproszenie oraz kradzieże, została uratowana dzięki staraniom władz Biblioteki Jagiellońskiej. Za zgodą władz zakonnych została przeniesiona do Biblioteki Jagiellońskiej jako czasowy depozyt. Tu, po przeprowadzeniu niezbędnych prac ratunkowych (odgrzybiania) i inwentaryzacyjnych, została udostępniona badaczom. 
Pierwszeństwo w dziele „odkrywania” urody Srebrnej Góry oraz tajemnic mieszkających na niej krakowskich kamedułów przysługuje Franciszkowi Wężykowi, jednemu z najpopularniejszych w pierwszych dziesięcioleciach XIX w. polskiemu poecie ${ }^{23}$. Nie był on rodowitym krakowianinem. Urodził się w Witulinie na Podlasiu (7 X 1785), większość życia spędził jednak bądź to w Krakowie, bądź w najbliższej jego okolicy (od 1839 roku wiele miesięcy każdego roku spędzał w leżącym w pobliżu Skały dworze w Minodze). Po raz pierwszy przybył Wężyk do Krakowa w 1801 roku, po dwuletnim pobycie na pensji w Warszawie. Tu zapisał się w poczet słuchaczy Wydziału Prawa Uniwersytetu Krakowskiego (w ten sposób zrealizował życzenie ojca, choć uczęszczał także na wykłady z literatury). Przyszły dożywotni senator m. Krakowa studia swoje musiał w 1806 roku przerwać z powodu śmierci matki. Jesienią 1809 roku powrócił jednak do Krakowa, aby utrwalić z nim swoje związki. W tym czasie zaczął uprawiać twórczość literacką, udało mu się także nawiązać bliższą znajomość z czasowo przebywającymi w dawnej stolicy Polski czołowymi przedstawicielami polskiej elity intelektualnej: Julianem Ursynem Niemcewiczem, Onufrym Kopczyńskim oraz Stanisławem Staszicem. To właśnie wówczas, po wyprawie latem 1809 roku w towarzystwie gen. Jana Henryka Dąbrowskiego, Michała Andrzeja Horodyskiego i Józefa Kalasantego Szaniawskiego w okolice Krakowa („turyści” zwiedzili Tyniec, Bielany, Przegorzały, Ojców, Pieskową Skałę i dolinę Prądnika), napisał pierwszy zarys powszechnie znanego dziś poematu pt. Okolice Krakowa. Po kilku latach, w 1813 roku, ponownie udał się na wyprawę w podkrakowskie okolice, dzięki czemu poemat ten „dopełnił” i wydał w ostatecznej formie w Krakowie w 1820 roku.

Franciszek Wężyk prowadzi nas w swoim poemacie najpierw do zamku krakowskiego, by stąd - przez Rybaki, ujście Rudawy do Wisły, Kazimierz i Skałkę - zaprosić czytelników do zwiedzenia Zwierzyńca, Bielan i Tyńca. Opisawszy Górę Bronisławy i Kopiec Kościuszki, przez Wolę Justowską i Łobzów podąża do Krzeszowic, Tęczyna, Czernej i Olkusza. Zwiedzamy z nim źródła Prądnika, Pieskową Skałę, Ojców i Korzkiew, by przez Zielonki i Prądnik Biały dotrzeć do mogiły Wandy. Ważnym etapem poetyckiej wędrówki autora jest przeprawa przez Wisłę i wizyta na mogile Krakusa. Poeta kończy swój poemat opisem Wieliczki i opowieścią o pożarze w tamtejszej kopalni.

${ }^{23}$ Por. B. Czwórnóg-Jadczak, Klasyk aż do śmierci. Twórczość literacka Franciszka Wężyka, Lublin 1994. 
Już po tym prostym przywołaniu widać, że wędrówka poety została opracowana solidnie, $\mathrm{z}$ określonym planem. Co więcej, Wężyk starał się w swoim poemacie zrealizować „program” ideowy, który ujawnił w pierwszych partiach poematu, stwierdzając: „Ojców ziemię ojczystym chcę uwielbić pieniem”24. Zamysł ten pisarz rozwija, precyzując w dalszych partiach utworu, o jaką to ziemię mu chodzi:

Śpiewać będę kraj błogi, którego wnętrzności

Pierwszych ojców ojczyzny przechowują kości.

Śpiewać chcę, jeśli rzeczy głos wydoła słaby,

Bogactwa i pamiątki, wdzięki i powaby

Ziemi, na której łono natura wspaniała

Wszystkie skarby swych darów z hojnością rozlała (s. 4).

Znamienne, że zanim jeszcze Wężyk wyprowadzi nas w okolice Krakowa, zwiedzamy z nim wawelskie wzgórze. Nie pokazuje on tu jednak „bogactw, wdzięków i powabów”, ale ruiny dawnej chwały. W tym - jak pisze - „grodzie Bolesławów, Zygmuntów, Stefanów”, którzy „rozciągnęli swe berło od morza do morza”, którzy przyjmowali „hołd władców i ludów pokłony”, dziś są tylko ruiny, a w części nich urządzono przytułek dla nędzarzy. Skarży się też poeta, iż „żaden mściciel nie zrodził się z kości Ojców”, że na Wawelu „śpią w grobach przemożni królowie" (s. 6). Być może wątek ten był mu potrzebny do stworzenia nastroju nostalgii za epoką, która bezpowrotnie odeszła w przeszłość. Prowadząc nas bowiem do coraz to innej podkrakowskiej miejscowości, nie szuka w nich dowodów żywotności współczesnego narodu, ale opisuje pamiątki po dawnej przeszłości. Poeta stworzył w ten sposób swoisty poetycki przewodnik po okolicach Krakowa, w którym opowiada przede wszystkim o zachowanych śladach dawnej historii przodków. Tylko od czasu do czasu przerywa ten wątek wspomnień, by ożywić narrację czy to związanym z Tyńcem podaniem o Heligundzie i Walgierzu czy też opowieścią o bielańskich kamedułach.

Fragment poświecony Bielanom poeta skonstruował na zasadzie kontrastu. Najpierw głosi on urodę krainy, nieledwie rajskiej:

Gdzie tylko zwrócę oko, widzę kraj wesoły.

Tu wszystkie w jeden powab zbiegły się żywioły:

Tu stalsza piękne niebo rozjaśnia pogoda,

24 F. Wężyk, Okolice Krakowa. Poema, wydanie drugie, poprawione i pomnożone, Kraków 1823 , s. 3. Kolejne cytaty z tego wydania (odnotowane zostają tylko strony). 
Tu jest lżejsze powietrze, przeźroczystsza woda.

Tu warowne schronienie od słonecznej spieki.

Tu drzewa, których pożyć nie zdołały wieki,

Godząc się bez oporu z posępną zaciszą,

Nigdy bujnymi szczyty z szumem nie kołyszą;

Tu Wisła u stóp góry poważnie płynąca,

Rzadko nurty spienione o brzegi roztrąca.

Wyższość miejsca, przedmiotom wyższości przyczynia,

Las panuje nad górą, nad lasem świątynia (s. 10).

Wyśpiewawszy pochwałę przyrody bielańskiej („Jakaż twoim pięknościom wyrówna pochwała?”) wprowadza nas Wężyk w otwarte „świątyni podwoje”. $\mathrm{Z}$ tą chwilą zmienia się jednak zasadniczo ton utworu. Radosny nastrój, który towarzyszył nam przed chwilą, ustępuje miejsca ciszy i zadumie:

Porzućmy u tych progów świata niepokoje,

A pomnąc, że przed bóstwa stanąć mamy tronem,

Z sercem od żądz natrętnych wnijdźmy oczyszczonym.

Jakaż cichość kościelne osiadła sklepienie!

Nigdy w nim głosów ludzkich uroczyste brzmienie,

Ni dźwięki, które organ roztacza wspaniały,

Przesyłanych do niebios modłów nie przerwały (s. 11).

Mimo pozorów nie wiadomo, czy Wężyk rzeczywiście zwiedzał erem bielański. Wiele wskazuje bowiem na to, że jednak nie przekroczył jego bram, a informacje o nim zaczerpnął z rozpowszechnionej głównie wśród ludu legendy. Wskazują na to kolejne, co najmniej dziwne, jego stwierdzenia. Pisze zatem o tym, jakoby w kościele (a może i w domkach pustelników?) znajdowały się jakieś napisy wzywające do milczenia („Każda ściana w napisach wzywa ku milczeniu”). Sam erem zaś jest - jego zdaniem - „siedliskiem smutku i żałoby”:

Tu widzimy umarłych, tam żyjących groby.

W nich zakonnik od zgiełku i ludzi daleki,

Słodzących życie związków zrzekłszy się na wieki,

By żadnym ich wspomnieniem nie był udręczony,

Od własnych nawet braci mieszka odłączony:

Rozmyślaniem o śmierci bez przerwy zajęty,

I śmierć wszystkie na pamięć przywodzą mu sprzęty (s. 11). 
Po tych zapowiedziach przychodzi znany z ludowej legendy finał, potwierdzający, że Wężyk chyba rzeczywiście nigdy nie przekroczyłbram bielańskiego eremu. Owszem, wspomina on o uprawie przez zakonników ogródków (ma to być - jego zdaniem - ,jedna [ich] rozkosz niewzbronna surowymi kary”), ale każdego czytelnika musi porazić inna informacja: oto bowiem każdy kameduła - zdaniem poety - nie tylko jest gotów umrzeć, ale i codziennie śmierć tę oswaja:

Co dzień gotów doczesne w wieczne zmienić życie,

Trumnę ma on za łoże, a kir za pokrycie (tamże $)^{25}$.

Ta informacja, nawet jeśli autor zaczerpnął ją z ludowej legendy, wskutek licznych przedruków poematu ${ }^{26}$ stała się najprawdopodobniej tekstem „kanonicznym" dla czarnej legendy o bielańskich kamedułach śpiących w trumnach i przykrywających się kirem! To był niedobry wkład Wężyka w literackie dzieje bielańskich kamedułów. Wkład, który wprawdzie przetrwał w legendzie, ale na szczęście nie został podjęty przez następców poety.

Nie podjął tego motywu legendy Paweł Czajkowski, uczony uprawiający także poezję, który w 1815 roku - z rekomendacji Dyrekcji Edukacji Narodowej Księstwa Warszawskiego - objął w Uniwersytecie Krakowskim katedrę literatury polskiej. Nie był on - podobnie jak Wężyk - rodowitym krakowianinem. Pochodził z Pomorza. Pierwsze nauki pobierał w Chełmnie. W Berlinie studiował filozofię. Przez pewien czas przebywał we Francji. Kilka lat spędził w Warszawie jako urzędnik Komisji Żywnościowej i Dyrekcji Własności Narodowych. Przed przybyciem do podwawelskiego grodu był nauczycielem w szkołach departamentowych w Toruniu. Z tego miasta Dyrekcja Edukacji Narodowej skierowała go do Krakowa.

Przed objęciem stanowiska profesora Uniwersytetu Krakowskiego Czajkowski odbył wielogodzinny egzamin konkursowy (zapowiedź kolokwium habilitacyjnego!), który trwał dwa dni, tzn. 3 i 4 lipca 1815 roku. W drugim dniu egzaminu czteroosobowa komisja egzaminacyjna, której przewodniczył prof. Jerzy Samuel

25 Znamienne, że już w pierwszej wersji poematu, którą Wężyk stworzył w 1809 roku i ogłosił drukiem w tym samym roku na łamach „Pamiętnika Warszawskiego”, znajdujemy ten motyw. Czytamy zatem, iż każdy bielański zakonnik „swój grobowiec wykuł za żywota // A pomnąc że co chwila śmierć go dotknąć może // Trumny w swoim spoczynku używa za łoże” („Pamiętnik Warszawski” 1809, t. 3, s. 203).

${ }^{26}$ Jak wspomniano, poemat Wężyka w pierwszej wersji pojawił się już w 1809 roku, w „Pamiętniku Warszawskim”. Kolejne wydania przypadają na lata: 1820, 1823, 1833, 1881, 1896 etc. W 1881 roku w Chicago ukazał się także przekład poematu na język angielski (kilka wznowień). 
Bandtkie, poleciła Czajkowskiemu m.in. zadeklamować jego własny wiersz o Bielanach $^{27}$. Ten sam wiersz autor czytał także w czasie "prywatnego" posiedzenia Towarzystwa Naukowego Krakowskiego w dniu 15 czerwca 1818 roku. Wydał go wówczas także drukiem. Dzięki temu możemy dziś się z nim zapoznać, przechowywany jest bowiem w postaci druku ulotnego w Bibliotece Jagiellońskiej.

Nie jest to utwór wysokich lotów. Pisany 13-zgłoskowcem, zgodnie z klasyczną teorią poematu opisowego, stara się zachować dystans wobec opisywanego obiektu. Owszem, poeta wygłasza pochwałę Srebrnej Góry i jej wspaniałego położenia w ostępach lasów, z chwilą jednak, gdy razem z nim wkraczamy w obręb murów eremu, mamy możliwość asystowania jedynie w mszy świętej odprawianej w kościele. Uczestniczą w niej pogrążeni w niemej kontemplacji mnisi. Nad całością obrazu dominuje atmosfera smutku i przygnębienia, którą potęguje grobowa kaplica:

Idąc na dół ostrożnie, mijam pierwsze stopnie:

Nagła bojaźń w mej duszy wzmaga się okropnie,

A płomień lichej lampy łamiąc cień ponury,

Obnaża dla mnie wkoło siarką zwilgłe mury.

Wyryta śmierć na zwłokach miesza moje czucie.

Znikomość mnie otacza, przeraża zepsucie,

A gdy nogą roztrącam ulotne popioły,

Lepiej znam ludzką nicość od Sokrata szkoły.

Tu cyprys z bluszczem sępią zapocone głazy;

Tu czytam na pół starte ręką lat wyrazy;

Tu imię i dzień zgonu. Myśl moja truchleje

Zważając jak to krótkie śmiertelnych są dzieje ${ }^{28}$.

Wizyta w eremie upływa nam pod znakiem grozy, potęgowanej dźwiękiem odzywającego się raz po raz z kościelnej wieży dzwonu, który

Jak stróż czasu swym młotem co chwila wspomina:

Że każdemu ostatnia wybije godzina ${ }^{29}$.

27 Szerzej na temat przebiegu egzaminu Czajkowskiego pisze Karol Lewicki w rozprawie Katedra Literatury Polskiej w Uniwersytecie Jagiellońskim w latach 1803-1848, [w]: Dzieje Katedry Historii Literatury Polskiej w Uniwersytecie Jagiellonskim. Zarys monograficzny. Ksiega zbiorowa, red. T. Ulewicz, Kraków 1966, s. 51-62.

${ }^{28}$ [P. Czajkowski], Majówka na Bielanach krakowskich, czytana przez P... C..., profesora literatury na posiedzeniu prywatnym Towarzystwa Naukowego dnia 15 czerwca 1818 roku, Kraków 1818, s. 5.

29 Tamże, s. 6. 
Poeta prowadzi nas także do domków, „w których mieszka ubóstwo z sumienia swobodą". Ale ta wizyta służy mu jako pretekst do wystąpienia w obronie zakonu, posądzanego o kultywowanie „samobójczych praw”:

Dobrowolna pokuta lub samotność nasza

Nie krzywdzi tak Ojczyzny jak przesąd ogłasza:

[...]

Ubóstwo naszym działem i pobożność szczera;

Kto z sobą żył szczęśliwie, szczęśliwie umiera.

Tu nikt na próżnej mowie chwili nie utraca

Pół dnia zabiera ołtarz a drugie pół praca ${ }^{30}$.

Tak oto wyprawa poety do eremu bielańskich kamedułów przeobraża się w apologię zakonu. Mimo motywów związanych z przemijaniem, bojaźnią Bożą, z wybijającym kolejne etapy życia dzwonem i bliską obecnością śmierci w podziemnej kaplicy Czajkowski nie kończy swojego dzieła - jak Wężyk - w nastroju przygnębienia i przerażenia. Przeciwnie, w ostatnim wersie zapowiada: „chcąc kiedyś czuć piękność, przybędę tu jeszcze" ${ }^{31}$. Wszystko wskazuje na to, że obietnicy jednak nie dotrzymał. W każdym razie nie stworzył kolejnego dzieła o Bielanach. Najprawdopodobniej nie miał nic więcej do powiedzenia o bielańskich kamedułach.

Wytyczonym przez tych twórców szlakiem podążył początkujący naówczas poeta lwowski Karol Bołoz Antoniewicz, który po latach miał zasłynąć jako autor do dziś śpiewanych w polskich kościołach „pieśni nabożnych” (Chwalcie łąki umajone; W krzyżu cierpienie, w krzyżu zbawienie; Zróbcie Mu miejsce, Pan idzie $z$ nieba i wiele innych), a także wytrawny kaznodzieja - misjonarz, przy tym jedna z najpiękniejszych postaci polskiego Kościoła w czasie zaborów ${ }^{32}$. W 1828 roku wydał on we Lwowie poemat pt. Bielany, wznowiony po roku - na korzyść Towarzystwa Dobroczynności w Krakowie. Jest to niewątpliwie interesująca „wprawka” młodego autora. Niewiele elementów krajobrazu znajdujemy w tym poemacie (Wisła, zamek tenczyński), niewiele także informacji o życiu uczniów św. Romualda (zwoływani w dzień i w nocy głosem dzwonu na modlitwy w świątyni). Więcej natomiast jest tu refleksji na temat sensu życia, jego przeznaczenia. Znamienne, że autor nie usiłuje zaskoczyć czytelnika opowieściami o trumnach-

$30 \quad$ Tamże, s. 7.

31 Tamże, s. 10.

32 Por. F. Ziejka, Ksiądz Karol od Krzyża (Ks. Karol Antoniewicz: kapłan - misjonarz - poeta), „Biuletyn Ormiańskiego Towarzystwa Kulturalnego”, 2009, nr 58/59, s. 6-26. 
-łożach pustelników czy o ich cierpieniach. Przeciwnie, znajdujemy tu pochwałę życia pustelniczego, a także ukazanie urody takiego życia:

Chcesz port pewny znaleźć? - uchodź na Bielany! -

Dzień schodzi za dniem w jednostajnym kole,

Łzy wyciska, nie rozjątrza bóle,

Echo jednej trącone godzinie

Przerywa ciszę i po skałach ginie

Tęczą nadziei, niebieskie sklepienie,

Tam nieraz serca wznosi się westchnienie,

Oko na jasnym spoczywa błękicie,

Gdzie wiara wieczne zapowiada życia! ${ }^{33}$

Niezbyt wysokich lotów poemat Antoniewicza stanowi zaledwie dokument czasu. Inaczej przyjdzie nam ocenić poetycki hołd złożony Srebrnej Górze przez Józefa Łapsińskiego, jednego ze wspaniale zapowiadających się poetów polskich epoki romantyzmu, którego świetnie zapowiadającą się karierę - wskutek złożonych wyroków Losu - przerwała przedwczesna śmierć. To jeden z najbardziej uzdolnionych uczniów Adama Mickiewicza. Urodzony w 1805 roku w Pieskowej Skale, już w dzieciństwie Łapsiński przeniósł się wraz z rodzicami do Białego Prądnika pod Krakowem. Uczęszczał do szkół krakowskich, w tym do Gimnazjum św. Anny, ale wskutek trudnych warunków materialnych maturę zdał dopiero w $1828 \mathrm{roku}$, $\mathrm{w}$ wieku 23 lat. W tym samym roku wstąpił na Uniwersytet Jagielloński, na Wydział Filozoficzny. Pozostając, podobnie jak wielu innych poetów galicyjskich owej doby (np. Jan Nepomucen Kamiński czy Karol Bołoz Antoniewicz), pod wielkim urokiem Mickiewicza, pisał przede wszystkim sonety i ballady. W 1829 roku utwory swoje postanowił wydać drukiem $\mathrm{w}$ osobnym tomiku. Ubogi $\mathrm{z}$ domu, wiecznie szukający gotówki, aby sprostać temu zadaniu, zaciągnął pożyczkę. Tomik poezji ukazał się drukiem, ale trzeba było pożyczkę spłacić. Wobec niemożności spłacenia długu młody poeta wpadł na tragiczny w konsekwencjach pomysł zdobycia niezbędnej kwoty 350 złp drogą szantażu: uznał, że sumę tę uzyska od powszechnie cenionego w Krakowie Floriana Straszewskiego, twórcy krakowskich Plant, a zarazem dzierżawcy krakowskiej loterii. Grożącego Straszewskiemu zabójstwem młodego poetę ujęła policja wieczorem 25 stycznia 1830 roku przy figurze Matki Boskiej Łaskawej stojącej naówczas przed kościołem kapucynów. Osądzony przez

33 K. Antoniewicz, Bielany, Lwów 1829, s. 8. 
władze rektorskie na 10 dni aresztu, został Łapsiński w trybie dyscyplinarnym usunięty z uczelni. Mimo okazanej mu pomocy ze strony kolegów studentów, poeta załamał się psychicznie. Przy najbliższej okazji skorzystał też z możliwości opuszczenia Krakowa. Jesienią 1830 roku znalazł się w Królestwie, gdzie właśnie trwały ostatnie przygotowania do powstania listopadowego. Jak podaje Kazimierz Sosnowski, autor ogłoszonego w 1901 roku studium o „poezji krakowskiej z czasów Wolnego Miasta 1815-1846", który powołał się na świadectwo swojego ojca, Franciszka, Łapsiński zginął w czasie utarczki z Kozakami po bitwie pod Grochowem w końcu lutego 1831 roku.

Wartościowy, choć skromny dorobek poetycki Łapsińskiego w pierwszym rzędzie zaleca się tematyką. Autor wykorzystuje - podobnie jak wspomniany wyżej Franciszek Wężyk - motywy krakowskie i podkrakowskie. Różni się jednak zasadniczo od poprzednika swoim stosunkiem do tej tematyki. Wywodzący się z nurtu klasyczno-sentymentalnego Wężyk traktował owe motywy przedmiotowo. Łapsiński tymczasem wprowadza do swoich wierszy ton osobisty, osobiste przeżycie. Różnicę w podejściu do poezji tych dwóch poetów widać na przykładzie ich stosunku do motywu Bielan. Franciszek Wężyk w swoim poemacie zastosował typową „wyliczankę":

Tu wszystkie w jeden powab zbiegły się żywioły,

Tu stalsza piękne niebo rozjaśnia pogoda,

Tu jest lżejsze powietrze, przeźroczystsza woda,

Tu warowne schronienie od słonecznej spieki,

Tu drzewa, których pożyć nie zdołały wieki.

$[\ldots]$

Tu Wisła u stóp góry poważnie płynąca,

Rzadko nurty spienione o brzegi roztrąca ${ }^{34}$.

Łapsiński daleki jest od takiego ujęcia. W swoim sonecie Bielany na wiosne nie szuka owego obiektywnego tonu, opisu pełnego dystansu wobec przedmiotu. Prowadzi nas za mury klasztoru, dzięki czemu stajemy się „uczestnikami” opisywanych wydarzeń:

Brzmi odgłos rannych modlitw w posępnym klasztorze,

Lśnią się jaskrawym świtem rozkwitnięte drzewa,

34 J. Łapsiński, Bielany na wiosnę, [w:] tenże, Poezje, Kraków 1829, s. 18. 
Wszędzie sztandar rozkoszy i życia powiewa,

Wonnych balsamów ranku rozlało się morze.

Poeta „dopełnia” opis tego urokliwego miejsca słowami:

Diamentem w tle rosy połyskuje zorze,

Król żyjącej muzyki swej kochance śpiewa,

Raz wznosi się głos tkliwy - znów słabnie, omdlewa,

I niknie w eterowym daleko przestworze ${ }^{35}$.

Łapsiński nie waha się odsłonić osobistego, pełnego akceptacji stosunku do opisywanego świata, czym wyraźnie sygnalizuje swój akces do nowej, romantycznej szkoły literackiej. Próżno szukać u niego tak typowych dla klasyków informacji o charakterze kulturowym, o których wzmiankowaliśmy przy omawianiu Okolic Krakowa. Zamiast tego znajdujemy w jego utworze typowe dla wczesnego romantyzmu motywy arkadyjskie. Jego Bielany to „edeński ogród”:

Cały dywan trawników w kwiaty haftowany,

Czysty szafir w czyściejszej odbija się wodzie.

Tam chatki, tu trzód stada bujają o chłodzie,

Dalej szumią doliny - łąki - złote łany -

Perło konchy tych krain, witam was Bielany!

To prawda, że młody poeta wspomina jeszcze o „odgłosie rannych modlitw w posępnym klasztorze”, ale ów odgłos modlitw nie burzy radosnego nastroju, jaki wywołały wprowadzone przez poetę do wiersza dalekie od śmierci motywy wiosenne, związane z budzącą się do życia naturą. To dlatego ów bielański sonet Łapsińskiego, podobnie jak cały jego tomik Poezji, można uznać za ważny etap w rozwoju poezji krakowskiej. Jest to zapowiedź nowej epoki owej poezji: epoki romantycznej, rozmiłowanej w pięknie przyrody. Tym torem pójdą następcy Łapsińskiego: bard Krakowa i jego okolic Edmund Wasilewski czy Anna Libera „Krakowianka”. Tym torem pójdzie także po latach Stanisław Wyspiański i cała gromada innych „poetów Krakowa”.

35 J. Łapsiński, Bielany na wiosnę w: tegoż, Poezje, Kraków 1829, s. 18. 
Poeci stworzyli nie tyle ścieżkę, co dość wygodną dróżkę wiodącą w stronę krakowskich Bielan. Ich utwory stały się drogowskazem, za którym coraz liczniej zaczęli podążać przedstawiciele elity polskiej, w tym pisarze i poeci. Jednym z pierwszych wielkich podróżników-pątników po ziemi ojczystej, który dotarł na krakowskie Bielany, był Julian Ursyn Niemcewicz. Przybył on tu w dniu 12 lipca 1811 roku. Zachwycił się też przede wszystkim wspaniałą okolicą. Znany pisarz, a także polityk i przyjaciel Kościuszki nie zagłębia się w historię kamedułów (choć podaje kilka ważnych z niej szczegółów), nie rozwodzi się nad istotą ich reguły, uwagę swoją skupia natomiast na urodzie otaczającej Bielany okolicy. Pisze: „Uważałem, iż im bardziej zakon jaki w ustawach swoich rwał z ludźmi i światem wszystkie towarzystwa związki, tym bardziej miejsca schronień jego wybrane są w zachwycających pięknością swoją położeniach, jak gdyby pustelnicy ci, wdziękami natury za stratę powabów towarzystwa nagradzać chcieli. Trzeba by ściśle kartuza lub kamedułę jakiego wyspowiadać, żeby dociec, czyli nagroda ta jest dostateczną"36. Niestety, wszystko wskazuje na to, że Niemcewicz nie zdołał w swej wędrówce po ziemiach dawnej Polski nawiązać bliższego kontaktu z pustelnikami bielańskimi. Swoje uwagi o nich ograniczył jedynie do podkreślenia wyższości zakonów kontemplacyjnych nad innymi, w czym można doszukać się pogłosów tak głośnej w oświeceniu krytyki życia monastycznego. Inaczej na kamedułów spogląda młodsza znacznie od Niemcewicza, ale wyrosła z tej samej szkoły literackiej Klementyna z Tańskich Hoffmanowa. W 1827 roku w swej wędrówce po ziemiach polskich przybyła także do Krakowa. W czasie pobytu w dawnej stolicy Polski, w dniu 28 maja, czyli w drugi dzień Zielonych Świątek, odwiedziła bielański erem, który - jak wiadomo - w tym dniu zawsze jest otwarty dla publiczności. Hoffmanowa zachwyciła się przede wszystkim otoczeniem eremu. Nie mniejsze wrażenie wywarli na niej pustelnicy. Czytamy zatem w jej dzienniku: „Mnie tak się podobały Bielany, ten widok czarujący, te domki schludne i wygodne, te ogródki takie ładne i tak bogate w kwiaty, a nade wszystko ta samotność i to milczenie, że w uniesieniu szczerze się zapytałam przewodnika, czy gdzie kamedułek nie ma. - Żaden twórca zakonów tak okrutnym nie był, ażeby miał zakazać kobietom mówić! - odpowiedział"37.

36 J. U. Niemcewicz, Podróże historyczne po ziemiach polskich od 1811 do 1828 roku, Petersburg 1859, s. 44.

${ }^{37}$ K. z Tańskich Hoffmanowa, Opisy różnych okolic Królestwa Polskiego, t. 2, [w:] taż, Wybór pism, Wrocław 1833, t. 6, s. 92. Nieco wcześniej, bo u progu XVIII wieku, o wstąpieniu do kamedułów myślał wzmiankowany tu Ambroży Grabowski. Po latach pisał: „Kiedym był jeszcze 
Bielany znalazły wiernego admiratora w osobie Ambrożego Grabowskiego, jednego z najbardziej zasłużonych dla Krakowa „starożytników”. O kamedułach bielańskich wspomina on wiele razy w swoich pamiętnikach (pisze tam nawet o bliskiej mu w pewnym czasie idei wstąpienia do ich zakonu). Poświęcił im sporo miejsca także w cieszącej się wielkim powodzeniem wśród czytelników, wydanej w 1836 roku pracy pt. Kraków i jego okolice. To prawda, że skupił się on przede wszystkim na historii klasztoru i kościoła Ojców Kamedułów, ale inkrustując swoją opowieść wynalezionymi u różnych autorów informacjami, nie omieszkał zwrócić uwagi czytelnika na powaby Srebrnej Góry. Przekonuje też czytelnika, że „Na wierzchu [tej] góry powietrze lekkie i czyste, woniejące balsamem przez rośliny i kwiaty uronionym, gwar ptactwa i rozległy widok nad przestrzenią przejmują rozkoszą zachwycającą i dla zmysłów miłośnika natury upojonego pięknościami jej orzeźwienie zanoszą"38.

Zarówno Niemcewicz, jak Hoffmanowa czy Grabowski, doceniając walory Bielan krakowskich, nie rozwodzą się szerzej nad nimi. Inaczej postępuje Józef Mączyński, autor obdarzony niewątpliwym talentem narracyjnym. Ten dziś zapomniany, a jakże zasłużony dla podwawelskiego grodu autor trzytomowej $\mathrm{Pa}$ miątki z Krakowa (1845) już na początku swojej opowieści o Bielanach zaskakuje świeżością ujęcia. Pisze: „W zachodniej stronie miasta [Krakowa], na najwyższym punkcie naszego widnokręgu, odsłania nam się okolica ślicznym łukiem lasu, z którego jakby ręce wzniesione do nieba, podnoszą się dwie kościelne wieże, i zachęcają tak silnie ku sobie, że nikt się nie zraża przez gęsty las dębów, jodeł i buków, po drodze skalistej, dostać się na tę panującą nad całą okolicą górę, stanąć u progów koronującej jej szczyt świątyni” ${ }^{39}$. Na dalszych kartach opowieści Mączyńskiego znajdujemy sporo informacji o powstaniu bielańskiego eremu. Autor przywołuje - za Michałem Wiszniewskim, autorem Historii literatury polskiej - fałszywą opowieść o tym, jakoby już w 1010 roku Bolesław Chrobry miał sprowadzić do Polski pierwszych kamedułów, ale, co ważniejsze,

18-letnim młodzieńcem, gdy mi stanęła na myśli przyszłość moja i niepewność losu, jaki mię oczekuje, i czy na drodze życia znajdę przed sobą kawałek chleba, w szeregu różnych marzeń stawała i myśl, że w razie niepowodzenia stoi przede mną otwarta furta klasztoru bielańskiego i że biały płaszcz Romualda i trepki z klockami drewnianymi u podeszew zasłonią przed pociskami twardego losu... Odwiedzając zakonne domki kamedulskie i ogródki ich, pełne kwiatów, podobało mi się to życie samotne i nęciło mnie ku sobie, ale Najwyższa Opatrzność inaczej rozrządziła dniami moimi i los mój uczyniła znośnym, za co niechaj będą Jej najserdeczniejsze moje dzięki”, A. Grabowski, Wspomnienia..., dz. cyt. s. 284.

38 [A. Grabowski], Kraków i jego okolice. Opisał historycznie A... G..., Kraków 1836, s. 218.

39 J. Mączyński, Pamiątka z Krakowa. Opis tego miasta i jego okolic, Kraków 1845, t. 3, s. 212. 
idąc za autorami romantycznymi, w tym i za naszym Łapsińskim, nasyca swoją narrację nastrojowym tonem. Dzięki temu jego Bielany przeistaczają się w prawdziwy raj na ziemi. Oto znamienny przykład metody tego autora, zastosowany przy opisie wnętrz bielańskiego kościoła: „Gdy koło tych kaplic przesuwają się w swych habitach zakonnicy, wtedy złudzonemu oku śnieżyste zwoje ich sukien przedstawiają zbiegłych z niebios aniołów, co tu z białymi skrzydeł puchami ukorzyć się przybyli przed majestatem Wszechstwórcy; kiedy zaś obległszy ołtarz wielki Wniebowzięcia Najś[więtszej] Panny zanucą smętnym głosem pieśń pobożną, a ty swe myśli i uczucia modlitwą oczyścisz, wtedy umysł dziwami stworzenia przejęty, samotną ciszą pustyni uspokojony, wzniesie się do Boga, a Bóg po promieniu wiary w całym blasku w twe wierzące serce zstąpi i balsamem niebieskiej pociechy ziemskie cierpienia zagoi” ${ }^{30}$. Słów tych nie skreślił już straszący trumnami i kirem przedstawiciel klasycyzmu, ale pisarz na wskroś romantyczny, tworzący świadomie nowy obraz Bielan jako oazy spokoju i modlitwy, skupiającej ludzi stojących bliżej Stwórcy niż my, zwyczajni czytelnicy, ludzie grzeszni. Mączyński nie szczędzi nam opisu poszczególnych kaplic kościelnych, przywołuje przed nasze oczy także zgromadzone w owych kaplicach obrazy oraz rzeźby. Co więcej, nie zapomina o znajdujących się tam katakumbach. Ale owe katakumby nie przerażają go. Zostały bowiem „obłaskawione” stwierdzeniem: „Patrzą co dzień na przyszłych swych mieszkańców błagających tu Boga, aby zmarłym i im po śmierci dał szczęśliwe życie wieczne"41. W domkach pustelników próżno szukać u tego autora trumien. Są natomiast łóżka białym suknem nakryte. Każdy domek zaś otoczony jest ogródkiem „w najpiękniejsze kwiaty ubranym". Gdy czytamy ten opis krakowskich Bielan, nie dziwią nas partie książki poświęcone wspaniałym widokom rozciągającym się czy to $\mathrm{z}$ ogrodów kamedulskich, czy też spod krzyża stojącego przed klasztorem. Autor nie zapomina o zwyczaju spędzania przez krakowian u bram klasztoru Zielonych Świątek ${ }^{42}$. Zwraca jednak uwagę na to, że po owych dwóch dniach majówek, „po tej chwilowej wrzawie, w te miejsca dawna wraca się uroczysta cisza, przerywana jedynie odgłosem klasztornego dzwonka, albo śpiewem leśnego drzew mieszkańca"43.

40 Tamże, s. 213.

41 Tamże.

42 Początkowo odpust na Bielanach obchodzono w dniu 19 czerwca, tzn. w rocznicę śmierci św. Romualda (dzień św. Gerwazego i św. Protazego). W okresie Rzeczpospolitej Krakowskiej odpust ten przeniesiono na okres Zielonych Świątek.

${ }^{43}$ J. Mączyński, Pamiątka z Krakowa..., dz. cyt., s. 220. 
Mączyński stworzył pewien wzór postrzegania Bielan i kamedułów. Jego opis jest już prawdziwym otwarciem bram bielańskiego klasztoru dla literatury pięknej. Każdy też z kolejnych autorów czy to przewodników po Krakowie i jego okolicach, czy też utworów literackich będzie się odwoływał do jego sposobu pisania o Bielanach. Każdy będzie starał się podkreślić urodę miejsca, ale także rozciągających się z niego widoków na Kraków i Tyniec, Lanckoronę i Kalwarię, na Babią Górę i Karpaty.

\section{5}

Pora na słowo ostatnie. To prawda, że o kamedułach z podkrakowskich Bielan mówi się w Polsce od ponad czterystu lat. To prawda, że powstała o nich i ich siedzibie spora biblioteka prac naukowych, popularnonaukowych i albumów. Ale prawdą jest także i to, że to dopiero z chwilą utraty niepodległości przez Polskę, gdy wskutek decyzji nieprzyjaznych Kościołowi władców zaborczych zlikwidowano większość eremów kamedulskich na polskich ziemiach, Bielanmi krakowskimi zaczęto się interesować. „Otwierali” im drzwi do polskiej literatury poeci. Drogę do serc coraz liczniejszych w epoce narodowej niewoli pątników otwierali im publicyści, a przede wszystkim - autorzy przewodników. Franciszek Wężyk stoi u początków nieoczekiwanego awansu Bielan w literaturze polskiej. Nowe perspektywy przed Bielanami otwarli ludzie pokroju Józefa Łapsińskiego czy Józefa Mączyńskiego. Każdy z przywołanych tu ludzi zapisał swoją kartę w dziejach „odkrywania” Bielan i ich od czterystu lat lokatorów: „zbiegłych z niebios aniołów!”. A przy tym zwyczajnych ludzi, podobnych do nas. 


\section{Riassunto}

\section{Oh, perla di conciglia di questa terra, ti saluto, Bielany!}

\section{La scoperta della bellezza di Bielany e dei secreti dei monaci camaldolesi}

Larticolo è un tentativo di una ricostruzione di un "processo della scoperta" della bellezza di Bielany da parte degli scrittori e dei poeti della prima metà dell'Ottocento. Lautore, dopo aver brevemente descritto la storia del monastero, si concentrò sulle testimonianze poetiche che lo riguardano. Il poeta più dedicato alla bellezza di questo luogo di culto fu Franciszek Wężyk, un poeta di Cracovia, noto a tutti gli abitanti grazie al suo poema "Okolice Krakowa" ("Dintorni di Cracovia"). L'esempio di Wężyk provocò la crescita di un gruppo notevole di altri autori: Paweł Czajkowski, Karol Bołoz-Antoniewicz, Józef Łapsiński, e il più grande di loro, Wincenty Pol. Lopera di questi poeti fu appoggiata anche dai grandi scrittori: Julian Ursyn Niemcewicz, Klementyna in Tański Hoffmann e Józef Mączyński. Grazie a loro gli eremiti trovarono un posto stabile sulle pagine della letteratura polacca. 